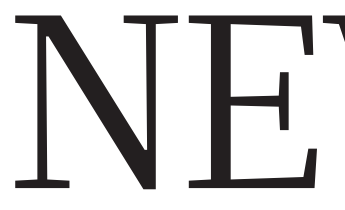

\section{TECHNOLOGY IBM}

commercializes quantum

cloud computing p.159
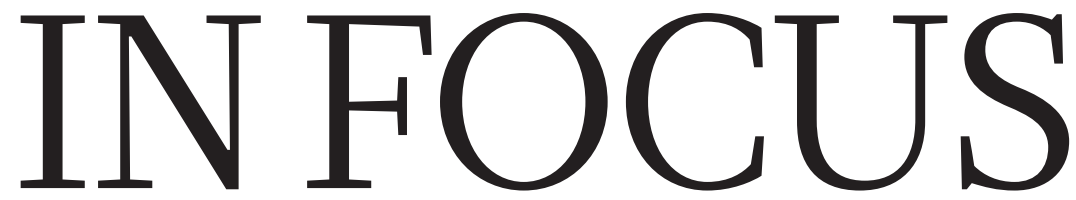

ARTIFICIAL INTELLIGENCE Poker

bots beat humans in game of incomplete information $\mathbf{p . 1 6 0}$
PSYCHOLOGY Resignation dispute puts spotlight on push for open data $\mathbf{p . 1 6 1}$
PHYSICS Time crystals

bring a wild idea to life p.164

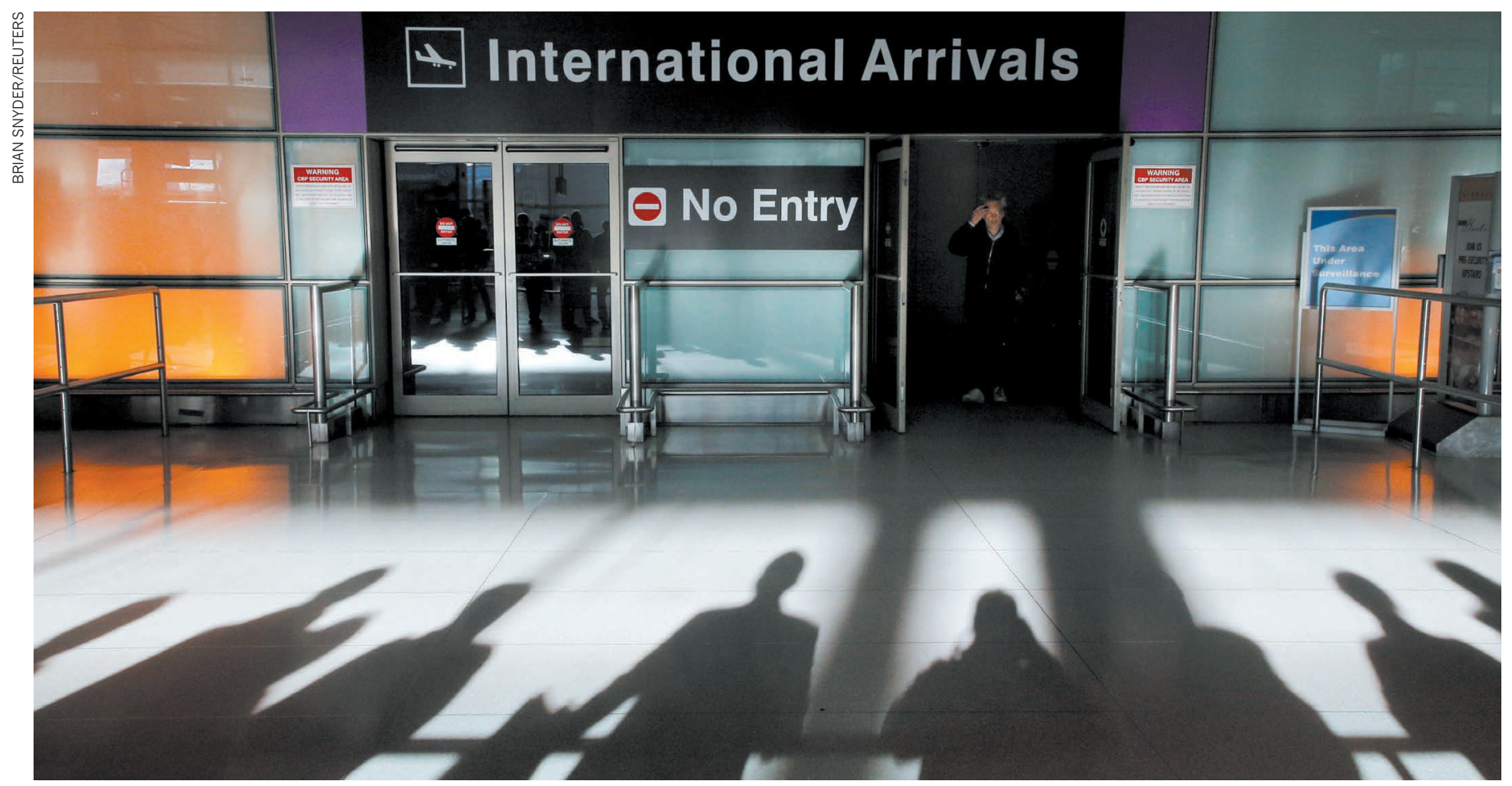

Many foreign-born scientists with US visas are reluctant to leave the country while immigration rules are in flux.

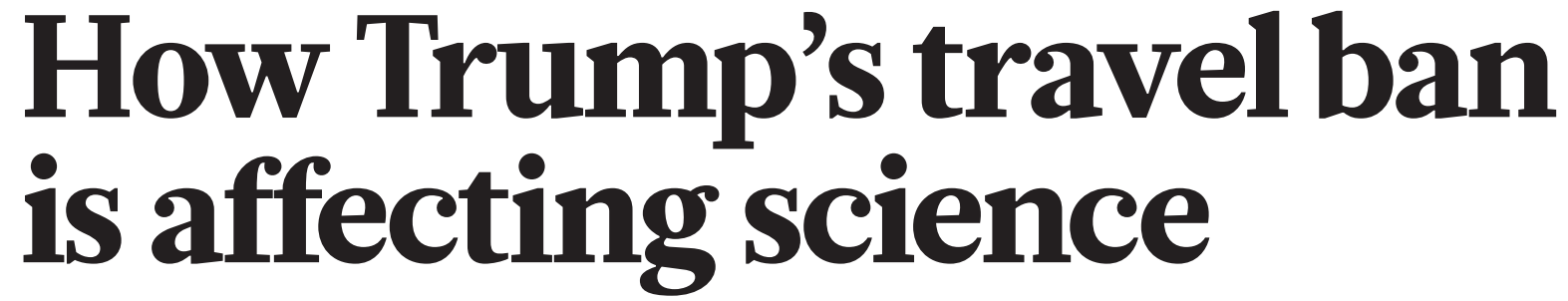

Researchers are cutting short travel, ending collaborations and rethinking their US ties.

BY SARA REARDON

$\mathrm{H}$ ani Goodarzi is sticking close to home these days. The cancer biologist at the University of California, San Francisco, cancelled a talk in late January at the University of Calgary in Canada and has put international travel on hold indefinitely. That's because Goodarzi, an Iranian citizen and US permanent resident, is afraid that if he leaves the United States he might not be let back in.

$\mathrm{He}$ is not alone. Many foreign-born scientists say they are reconsidering plans to work or study in the United States, given US President Donald
Trump's attempts to restrict immigration. On 27 January, Trump signed a ban that sought to deny entry to citizens of 7 Muslimmajority nations for 90 days, including people with valid US visas. Federal courts have temporarily blocked the policy, pending legal challenges, but on 6 March Trump tried again with a revised ban that targets six of the original countries - exempting current visa holders and citizens of Iraq.

The new policy is almost certain to face a fresh wave of lawsuits, but some researchers worry that the Trump administration will nonetheless continue to expand limits on who can visit or live in the United States. This lingering uncertainty over US immigration rules is prompting some scientists to curtail crucial research trips and may dissuade other researchers, students and entrepreneurs from considering the United States as a destination.

"There is this spread of psychology of fear," says Mustafa al'Absi, a behavioural scientist at the University of Minnesota in Duluth. "This is where the burden is: what's going on in the air, more than the facts.'

The original Trump ban affected citizens of Iran, Iraq, Libya, Somalia, Sudan, Syria and Yemen - including those who had already 


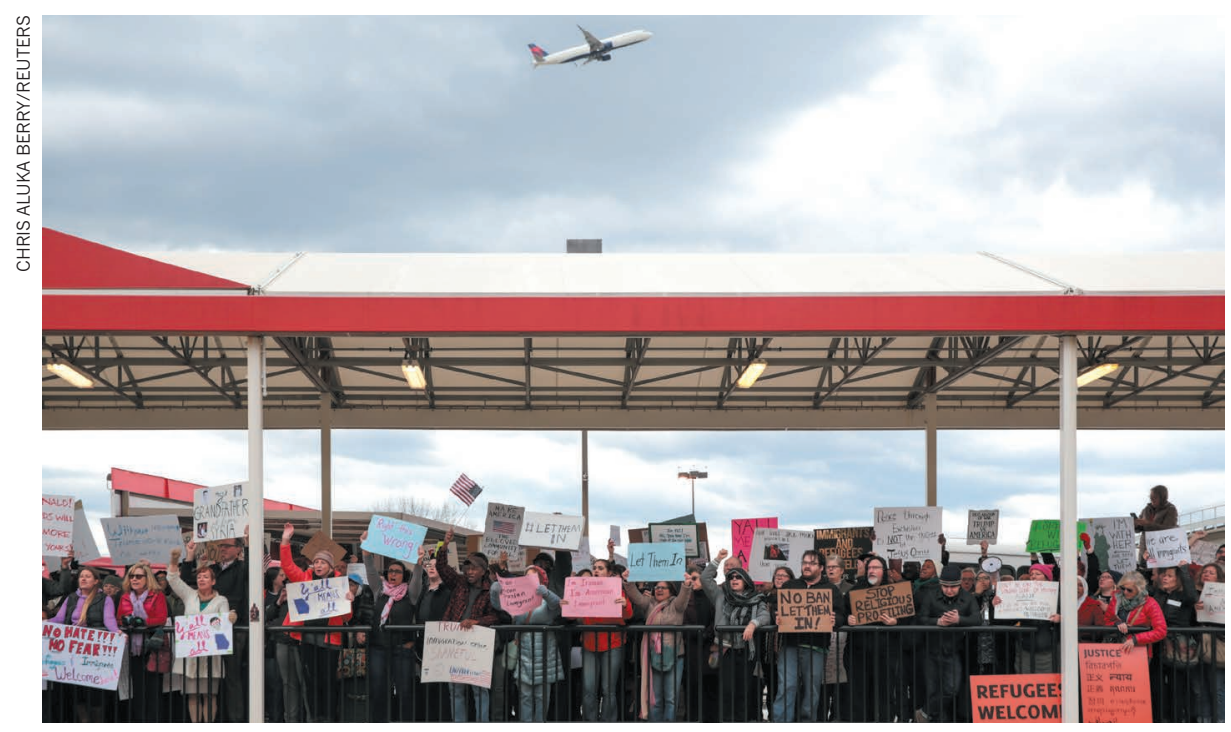

Donald Trump's first travel ban drew protests at airports around the United States.

secured permission to visit or live in the United States. In the first days after the policy took effect, numerous reports surfaced of students and faculty members from US universities who were trapped overseas or detained at airports.

\section{BROKEN LINK}

Even though the ban was quickly blocked pending legal challenges, and has now been superseded by a revised version, many institutions are still playing it safe. "All foreign nationals should carefully assess whether it is worth the risk to travel outside the country," officials from Harvard University in Cambridge, Massachusetts, said in a 28 January letter to students and faculty - advice that is still in place for people from the affected countries. Researchers at other universities told Nature that they had received similar guidance.

Goodarzi says that he will leave the United States only in an emergency, even though the White House acted to exempt permanent residents from the original ban before the courts intervened. "I don't think I can risk it at this time," he says. That will prevent him from attending international meetings that could help to establish his scientific reputation as he builds a new lab.

Similarly, al'Absi and his colleagues at the University of Minnesota have ended a collaboration with researchers in Yemen to study the mental-health effects of khat, a recreational drug commonly taken in parts of Africa and the Middle East. The US group had scaled back the project a few years ago in response to political upheaval in Yemen, but the prospect of working there at all seems impossible now given the direction that US immigration policy has taken, al'Absi says.

An Iranian-American astronomer, who did not want to be named because he has international travel coming up, says that the vetting process to enter the United States is already very strict. He went through fingerprinting and multiple interviews to get permanent residency and, later, his US citizenship. "It's not like giving out candies," he says.

It is not clear whether the current uncertainty over immigration will dissuade foreign students from attending US universities. More than 216,000 international students used temporary visas to enrol in science or engineering graduate programmes at US institutions in 2015, according to the US National Science Foundation. About 35,000 foreign-born people were working as postdocs in those fields.

"The worry we have is a snowball chilling effect," says Benjamin Corb, director of public affairs at the American Society for Biochemistry and Molecular Biology in Rockville, Maryland. Prospective students from places that were not included in Trump's latest ban may still wonder if their country could be affected in the future, and avoid the United States, he adds.
New York University, which has more international students than any other US institution, has not seen a decrease in interest from foreigners, says Thomas Sirinides, associate director of international student services. But applications to graduate programmes are not due until August, and by then the situation could change, he says. "If [international students] don't feel confident they can finish a degree, they don't want to come here to start a degree," Sirinides adds.

In Malaysia, a Muslim-majority country that was not included in the Trump ban, "there's confusion mixed with a little worry", says James Coffman, executive director of the Malaysian-American Commission on Educational Exchange in Kuala Lumpur. The political climate in the United States is one reason that Coffman expects fewer Malaysians to apply to US universities this year.

\section{SHIFTING CENTRE}

Half a world away, in California's Silicon Valley, investors and entrepreneurs are trying to work out how Trump's immigration policies will affect the thriving start-up scene - which draws heavily on foreign science and engineering talent. "If it's not friendly to stay here after you build your start-up, then why bother coming?" says Arvind Gupta, founder of IndieBio, a biotech accelerator programme in San Francisco, California.

Investors could also be put off if obtaining visas for start-up founders becomes harder or more expensive, he adds. Such fears have prompted Gupta to consider opening IndieBio's first office outside the United States.

Some science groups are trying to come up with their own creative solutions to the immigration problems. When the American Physical Society's international-affairs committee meets in May, its members will discuss how the society can blunt the effects of the travel ban.

Potential actions could include redoubling efforts to help foreign researchers obtain US visas, or setting up virtual mentorships and collaborations for young scientists outside the country, says Maria Spiropulu, a physicist at the California Institute of Technology in Pasadena and a member of the committee.

Still, Spiropulu is optimistic about the future. "We will remember this as a turbulent time," she says. "I cannot believe that this world will persist."

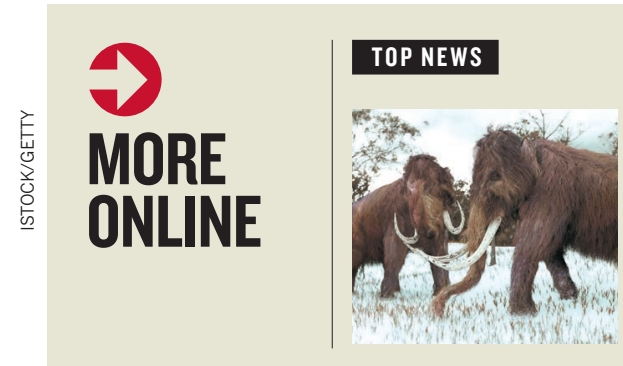

Dying woolly mammoths were in 'genetic meltdown' go.nature. com $/ 2 \mathrm{mmjb} 4 \mathrm{~b}$

\section{MORE NEWS}

- Amazon rainforest was shaped by an ancient hunger for fruits and nuts go.nature.com/21od8qt

- UK scientists welcome changes to research reforms go.nature.com/2mwxyu - Urban taxi-sharing follows universal maths law go.nature.com/2mhvzyd

\section{NATURE PODCAST}

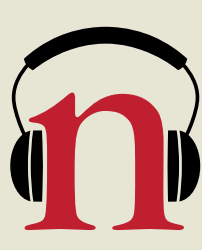

The earliest known life; Neanderthal self-medication; and data storage in a single atom nature.com/nature/ podcast 